\title{
Indigenous Knowledge on Rodent Management of the Ao-Nagas of Mokokchung District, Nagaland
}

\author{
Talisosang Amri* and J. Longkumer
}

Dept. of Agricultural Extension, School of Agricultural Sciences and Rural Development, Nagaland University, Medziphema Campus, Dimapur, Nagaland (797 106), India

\section{Corresponding Author}

Talisosang Amri

e-mail: tali.amri@gmail.com

\author{
Article History \\ Article ID: AR1849 \\ Received in 04 ${ }^{\text {th }}$ October, 2017 \\ Received in revised form $20^{\text {th }}$ October, 2018 \\ Accepted in final form $23^{\text {rd }}$ October, 2018
}

\begin{abstract}
The study of indigenous knowledge on rodent management of the Ao-Nagas of Mokokchung district, Nagaland, India was conducted during the period 2011-2012. Six villages covering the six ranges of Mokokchung District were selected purposively for the study and taking 16 respondents each from a village, making 96 respondents in total. $68 \%$ of the respondents still followed indigenous methods and while the rest 32\% followed modern management. Eight independent variables were selected for the study viz., age, sex, educational status, marital status, farming experience, mass media contact and extension agency contact and two dependent variables viz., Perceived Effectiveness of indigenous control method and extent of adoption of modern control method. In the study, it was found that $37.50 \%$ of the respondents belong to the category of $51-60$ years. $35.42 \%$ of the respondents had primary level of school education. Majority of the respondents (60.41\%) had more than 20 years of farming experience. $47.92 \%$ of the respondents had no mass media exposure and $67.71 \%$ of the respondents had no contact with the extension agencies. Five indigenous physical methods of rodent management were identified and documented viz., Longnen, Merang sang, Konglen, Tsüngtem and Tongi.
\end{abstract}

Keywords: Indigenous knowledge, rodent management, perceived effectiveness, Ao-Nagas

\section{Introduction}

Indigenous knowledge is primarily referred to the long standing traditions, belief and practices of certain regional, local and indigenous communities (Mahalik and Mahapatra, 2010). Indigenous knowledge (IK) can be described as knowledge which has been accumulated by the people over generations by observation, experimentation, and by transmitting orally old people's experience and wisdom in any particular area of human endeavour. For centuries, farmers have planned agricultural production and conserved natural resources with the instruments of indigenous knowledge (IK). Indigenous or traditional knowledge (TK) is used at the local level by communities as the basis for making decisions pertaining to food security, human and animal health, education, natural resource management and other vital activities (Gorjestani, 2000). Some traits of Indigenous Knowledge include oral tradition, undocumented, simple; dependent over the values, norms and customs of the folk life, production of notions through trial and error, accumulation of years of intellectual reasoning and understanding of day to day life experiences, practical rather than theoretical (Gupta, 2011).

Management of agricultural crops has been developed by the indigenous people using locally available resources and knowledge gained through observations. Almost every agricultural crop can be attacked by rodents and they have a significant effect on people's livelihoods viz., causing damage to rice and other crops, loss and contamination of stored rice, damage to buildings, contamination of food and water supplies, damage to personal possessions etc. Majority of the farmers follow the age old traditional practices of rodent management which is socially accepted and environmentally sound. The concept and use of EBRM (Ecologically-based rodent management) in some South East Asian countries were successfully applied which requires not only the environmental management but integration of all components like ecological, sociological and economical point of view (singleton et al., 2004). In a study conducted by Steve et al. (2009), trapping of rodents was carried out using a number of different methodologies and trap types in four different habitats: (1) bamboo forests, (2) crop fields, (3) inside houses, and (4) outside around villages, using a mixture of kill traps, single-capture cage traps, multicapture live-traps, and Sherman traps. People in Himachal Pradesh construct traditional fixed storage structure (Lakolu) to store seeds which is out of reach of rodents (Kanwar and Sharma, 
2006). A study conducted by Chandola et al. (2011) found that farmers in Kankapura district of Uttarakhand plant Gubasi mullu (Barleria baxifolia) around the grain storage area and field to keep the rats away as the plant has thorns. In Assam, for controlling rats in rice fields farmers put cycle tyre tubes near the mouth of the burrow which scares the rat due to its snake like appearance and pouring of vermilion (Sindoor) water on the captured rats and releasing them on the field scares the other rats away (Deka et al., 2006). Structures used by Adi tribes of Arunachal Pradesh made of locally available materials and toko palm was found to protect grains at maximum extent from storage pest (Sarangi et al., 2009).

This age old practice is gradually being lost as the younger generations are opting out for other employment avenues and shunning the traditional agricultural practices. Thus, this study was conducted in documenting indigenous practices of rodent management in Mokokchung district.

\section{Materials and Methods}

The present survey investigation was carried out during 2011-2012 of the Ao-Nagas of Mokokchung district, Nagaland to study the effect of Indigenous Knowledge on rodent management of the Ao-Nagas with respect to physical rodent management techniques.

\subsection{Locale of the study}

The study was undertaken in Mokokchung district of Nagaland, one of the 11 districts of Nagaland. Mokokchung district is further divided into six ranges viz., Tsürangkong, Japukong, Changkikong, Ongpangkong, Asetkong and Langpangkong. From each of the range, one village was selected purposively for the study viz., Longpayimsen, Longjemdang, Changki, Chuchuyimpang, Yisemyong and Changtongya. A total of 96 respondents were selected, taking 16 respondents from each village.

\subsection{Method of data collection}

Primary data was collected from the respondents with the help of interview schedule and group discussion. Secondary data was collected from relevant text books, journals, internet sources etc. For drawing valid conclusion, the collected data's were processed, classified, tabulated and systematically analyzed with the help of percentage, arithmetic mean, standard deviation (SD) and simple correlation coefficient.

\subsection{Selection of variables}

Independent variables which were selected for the study includes age, sex, educational status, marital status, farming experience, mass media contact and extension agency contact. Dependent variables include Perceived effectiveness of indigenous control method and Extent of adoption of modern control method.

\section{Results and Discussion}

3.1. Distribution of respondents according to independent

\section{variables}

It is evident from Table 1 that the majority of the respondents belonged to category of 51-60 years with $37.50 \%$ followed by the category of 61 years and above (28.12\%), $41-50$ years $(22.92 \%)$ and respondents under 40 years were $11.46 \%$. All the respondents were male and married. It was found that half

Table 1: Distribution based on independent variables ( $N=96)$

\begin{tabular}{|c|c|c|c|c|c|}
\hline $\begin{array}{l}\text { SI. } \\
\text { No. }\end{array}$ & $\begin{array}{l}\text { Vari- } \\
\text { ables }\end{array}$ & Category & $\begin{array}{c}\text { Per- } \\
\text { cent- } \\
\text { age }(\%)\end{array}$ & Mean & SD \\
\hline \multirow[t]{4}{*}{1.} & \multirow[t]{4}{*}{ Age } & Less than 40 years & 11.46 & \multirow[t]{6}{*}{53.47} & \multirow[t]{6}{*}{9.36} \\
\hline & & $41-50$ years & 22.92 & & \\
\hline & & $51-60$ years & 37.50 & & \\
\hline & & 61 years and above & 28.12 & & \\
\hline \multirow[t]{2}{*}{2.} & \multirow[t]{2}{*}{ Sex } & Male & 100 & & \\
\hline & & Female & 0 & & \\
\hline \multirow[t]{6}{*}{3.} & \multirow{6}{*}{$\begin{array}{l}\text { Educa- } \\
\text { tional } \\
\text { status }\end{array}$} & Illiterate & 50 & \multirow[t]{8}{*}{0.71} & \multirow[t]{8}{*}{0.89} \\
\hline & & $\begin{array}{l}\text { Primary level } \\
\text { school education }\end{array}$ & 35.42 & & \\
\hline & & $\begin{array}{l}\text { Middle level school } \\
\text { education }\end{array}$ & 10.42 & & \\
\hline & & $\begin{array}{l}\text { High level school } \\
\text { education }\end{array}$ & 2.08 & & \\
\hline & & $\begin{array}{l}\text { Higher Secondary } \\
\text { level education }\end{array}$ & 2.08 & & \\
\hline & & $\begin{array}{l}\text { Collegiate level } \\
\text { education }\end{array}$ & 0 & & \\
\hline \multirow[t]{2}{*}{4.} & \multirow{2}{*}{$\begin{array}{l}\text { Marital } \\
\text { status }\end{array}$} & Single & 0 & & \\
\hline & & Married & 100 & & \\
\hline \multirow[t]{4}{*}{5.} & \multirow{4}{*}{$\begin{array}{l}\text { Farming } \\
\text { experi- } \\
\text { ence }\end{array}$} & Less than 10 years & 5.21 & \multirow[t]{4}{*}{24.43} & \multirow[t]{4}{*}{7.15} \\
\hline & & $11-15$ & 5.21 & & \\
\hline & & $16-20$ & 29.17 & & \\
\hline & & $\begin{array}{l}\text { More than } 20 \\
\text { years }\end{array}$ & 60.41 & & \\
\hline \multirow[t]{4}{*}{6.} & \multirow{4}{*}{$\begin{array}{l}\text { Mass } \\
\text { media } \\
\text { contact }\end{array}$} & No. contact & 47.92 & \multirow[t]{4}{*}{1.08} & \multirow[t]{4}{*}{1.13} \\
\hline & & Mobile, T.V., Radio & 33.33 & & \\
\hline & & $\begin{array}{l}\text { Newspaper, Maga- } \\
\text { zine }\end{array}$ & 7.29 & & \\
\hline & & All & 11.46 & & \\
\hline \multirow[t]{3}{*}{7.} & \multirow{3}{*}{$\begin{array}{l}\text { Exten- } \\
\text { sion } \\
\text { agency } \\
\text { contact }\end{array}$} & Never & 67.71 & \multirow[t]{3}{*}{0.34} & \multirow[t]{3}{*}{0.52} \\
\hline & & Occasional & 30.21 & & \\
\hline & & Often & 2.08 & & \\
\hline
\end{tabular}


of the respondents were illiterate followed by primary level school education with $35.42 \%$, middle level school education $(10.42 \%)$, high level school education $(2.08 \%)$ and higher secondary level school education (2.08\%) respectively. The table indicates that $60.41 \%$ of the respondents had more than 21 years of farming experience followed by the respondents having farming experience of $16-20$ years with $29.17 \%$ and respondents under the category of 11-15 years and less than 10 years with $5.21 \%$ each. The table also indicates that $47.92 \%$ of the respondents had no mass media contacts followed by respondents under the category of mobile, T.V., radio with $33.33 \%$, newspaper and magazine category (7.29\%) and $11.46 \%$ of the respondents had all contacts with the mass media. Meanwhile $67.71 \%$ of the respondents had no contacts with the extension agencies followed by 'occasional' contacts with $30.21 \%$ and respondents under 'often' category was found to be only $2.08 \%$.

\subsection{Distribution of respondents according to dependent variables}

\subsubsection{Perceived effectiveness of indigenous control method}

Effectiveness is the capability of a material or non-material object to produce something or to lead to come to some consequences. For this study, the perceived effectiveness was operationalized as the extent of ability of that practice, as perceived by the farmers, in solving various problems by them in rodent management. Traits were identified for working out the Perceived Effectiveness Index (PEI) based on PEI calculation developed by Sundaramari and Ranganathan (2005). It was found that out of the total 96 respondents, 65 respondents were following indigenous practices. Accordingly the Perceived Effectiveness Index (PEI) was calculated for 65 respondents. Table 2 shows that the indigenous trap Konglen had a Mean Perceived Effectiveness Index (MPEI) of 2.62 followed by Longnen and Merang sang with MPEI of 2.24 each, Tsungtem with 2.18 and Tongi with 1.56 indicating that Konglen, Longnen, Merang sang and Tsungtem were considered as effective by the farmers, whereas Tongi was perceived as ineffective by the farmers.

Table 2: Distribution of respondents based on their Perceived Effectiveness ( $\mathrm{N}=65$ )

\begin{tabular}{lll}
\hline Sl. No. & Items & MPEI \\
\hline 1. & Longnen & 2.24 \\
2. & Merang sang & 2.24 \\
3. & Konglen & 2.62 \\
4. & Tsungtem & 2.18 \\
5. & Tongi & 1.56 \\
\hline
\end{tabular}

\subsubsection{Extent of adoption of modern control methods}

31 respondents were found to follow modern control methods such as snap traps, sticky gums and rodenticides like Roban, available in the market. But it was also found that all the respondents did not use all the control measures at the same time. Table 3 shows that Roban was used by all the 31 respondents $(100 \%)$, followed by sticky gum (N-rat) with $51.61 \%$ and traps with $38.71 \%$.

Table 3: Distribution of respondents based on modern methods ( $\mathrm{N}=31$ )

\begin{tabular}{llcc}
\hline $\begin{array}{l}\text { Sl. } \\
\text { No. }\end{array}$ & Items & $\begin{array}{c}\text { No. of } \\
\text { respondents }\end{array}$ & $\begin{array}{c}\text { Percentage } \\
\text { (\%) }\end{array}$ \\
\hline 1. & Rodenticide (Roban) & 31 & 100 \\
2. & Gum (N-Rat) & 16 & 51.61 \\
3. & Trap & 12 & 38.71 \\
\hline
\end{tabular}

3.3. Description of the identified indigenous rodent management practices

The indigenous practices of rodent management as found and identified were confined to the physical methods of rodent management. The indigenous control method of rodent management utilizes locally available materials and the techniques of such physical methods have been transmitted down through the generation and the usage of such management methods till date manifests its usefulness and effectiveness.

\subsubsection{Longnen}

"Long" means "stone" and "nen" means "to crush" in AoNaga dialect. It is used for catching rodents like rats, squirrels as well as birds. It is basically made of bamboo splits woven together like a mat; and stones are tied on top of the mat. The trap consists of a tongue (bamboo split) and a trigger. As the trigger is disturbed, the mat falls over the animal under the weight of the stone thereby crushing the animal. Another type of Longnen, Longpak Longnen was also reported which worked like the Longnen but instead of bamboo mat, a large flat stone was used. It was found that the use of Longnen was found to be practiced in all the villages.

\subsubsection{Merang sang}

It is used for catching animals of small to medium size such as rats porcupines, squirrels, wild hogs and sometimes deer are also caught. The trap is made depending upon the type of animal needed to be caught. "Merang" means "iron/steel" and "sang" means "trap" in Ao-Naga dialect. It is basically made of strong iron/steel wires used for earthing in electric post or at home. Sometimes the steel frame of the umbrella is also used. One end is folded and the other end is bent and inserted in the folded end, which looks like the letter " $D$ ". The trap consists of a trigger which is tied to the trap.This trap is usually set on the run-ways or placed in areas of high animal presence. It was found that the use of Merang Sang was practiced in all the villages.

\subsubsection{Konglen}

"Kong" means "neck" and "len" means "to tie" in Ao-Naga dialect. Some refer it as "Wanglet." It is basically made of 
bamboo splits, locally made strings or steel wires. One type of konglen, "Chepchu sang", is specifically used for catching porcupines. The word "Chepchu" means porcupine and "sang" means trap. Konglen is usually placed hanging on the run-ways and covered with surrounding leaves. Here a tree branch or matured, strong bamboo plant is pulled down and one end of the local made string/steel wire is tied on the tip of the branch. The other end is made into a noose with a trigger. The trigger is set with the help of a small twig or a thin bamboo split. Konglen was recorded to be practiced in all the villages.

\subsubsection{Tsungtem}

Tsüngtem is also used for catching variety of animals for which the size is made accordingly. The word "Tsüng" means "leg" and "tem" means "to set/to catch" in Ao-Naga dialect. It consists of bamboo strips with a noose end on one side and the other end is tied on a tree branch/bamboo plant after pulling it down. It works like the Konglen but it is set on the ground. As soon as the animal step its leg on the pit, it sets off the trigger where the pulled tree branch goes up, trapping the animals by their legs. It was also found that the use of Tsüngtem was found to be practiced in all the villages.

\subsubsection{Tongi}

Tongi was reported to be used by the people from Yisemyong and Changtongya. It is also made of bamboo. It somewhat acts like a scissor where two bamboo splits are tied together at one end and the other end of the lower bamboo split is tied on another bamboo keeping the upper split loose. Another bamboo split is attached on the upper loose split which acts like a spring. Tongi is set with the help of a trigger and placed on the run-ways. It is used for catching rats, porcupines etc.

3.4. Relationship between independent variables with indigenous control methods

It is observed from the Table 4 that the Mass Media Contact had a negative but significant correlation, which indicates that higher is the mass media contact, lower is the indigenous

Table 4: Correlation coefficient of indigenous control methods with the independent variable $(\mathrm{N}=65)$

\begin{tabular}{llc}
\hline $\begin{array}{l}\text { Sl. } \\
\text { No. }\end{array}$ & Independent variable & Correlation coefficient " $r$ " \\
\hline 1. & Age & $0.16565^{\mathrm{NS}}$ \\
2. & Sex & $\mathrm{NA}$ \\
3. & Educational status & $-0.22778^{\mathrm{NS}}$ \\
4. & Marital status & $\mathrm{NA}$ \\
5. & Farming experience & $0.171694^{\mathrm{NS}}$ \\
6. & Mass media contact & $-0.24573^{*}$ \\
7. & Extension agency & $\mathrm{NA}$ \\
& contact & \\
\hline
\end{tabular}

*significant at $(p=0.05)$ level of probability: NS: Non significant; NA: Not Available practices or vice-versa. The independent variables such as age, educational status and farming experience had non-significant correlation. Independent variables like sex, marital status and Extension Agency Contact were not available because of the fact that the respondents were all male, married and had no contacts with the extension agencies.

\subsection{Relationship between independent variables with modern control methods}

It is evident from the Table 5 that none of the independent variables had significant correlation with the modern control methods.

Table 5: Correlation coefficient of modern control methods with the independent variables $(\mathrm{N}=31)$

\begin{tabular}{llc}
\hline Sl. & Independent variable & Correlation coefficient " $r$ " \\
No. & & \\
\hline 1. & Age & $0.041555^{\mathrm{NS}}$ \\
2. & Sex & $\mathrm{NA}$ \\
3. & Educational status & $0.096042^{\mathrm{NS}}$ \\
4. & Marital status & $\mathrm{NA}$ \\
5. & Farming experience & $0.064265^{\mathrm{NS}}$ \\
6. & Mass media contact & $0.064465^{\mathrm{NS}}$ \\
7. & Extension agency & $0.041352^{\mathrm{NS}}$ \\
& contact & \\
\hline
\end{tabular}

*significant at $(p=0.05)$ level of probability: NS: Non significant; NA: Not Available

\subsection{Scope and Constraints in Adoption of Modern Control Methods}

During the course of the study, few scope and constraints were identified in adoption of modern control methods. The scope and constraints identified were all according to the respondent's points of view. Some of the scope identified during the study was that the use of rodenticide 'Roban' was found to be highly effective for all the 31 respondents who used it and were happy with the results. The modern approaches require less man-power as the method are readymade and does not require any laborious tasks to be carried out. The cost of maintenance and yield of crops in the field was improved due to the interventions of modern control methods. The constraints according to the respondents was that the rodenticides were used in the fields only because they were afraid the use of it in the residential area would be a threat to their children as well as their pets and expressed that the modern control methods were not available readily and the required amounts was also not available on demand. The respondents had to travel far distance to buy the materials required for rodent management. This involved expenditures which were often beyond the means of the respondents. The benefits of rodent management programmes and trainings were appropriated by a few select people, while the real 
farmers and those who were really interested were excluded. For instance, only the Village Council members and the more affluent people in the village were more benefited often than not the actual beneficiaries of the trainings. Most respondents expressed that there was poor contact of Agricultural Departments with the farmers. It may be noted that the scope for adoption of modern control methods is still very limited and require more dissemination from the concerned agencies through widespread trainings etc.

\section{Conclusion}

In Nagaland, indigenous practices and knowledge which had been transmitted from one generation to the next through the oral tradition is in peril. Therefore it was felt necessary to undertake the present study. It may be concluded that the identified indigenous practices may be tested, standardized and blended with modern technologies and recommended for use. Furthermore it may also be stated that there is an urgent need to document such indigenous knowledge before it is forgotten or lost.

\section{Suggestions for Further Research}

The present study was conducted only in a few select villages under Mokokchung district. Therefore similar studies may be conducted on a larger scale to explore the various indigenous knowledges and to make an inventory of traditional practices on rodent management. All the indigenous practices identified in the present study was the physical control measures, therefore the non-physical control measures could be an area of further study so as to contribute towards the documentation of indigenous knowledge. Further, a more intensive study may be conducted on the indigenous practices on cultivation practices, plant protection techniques, postharvest management and so on.

\section{References}

Chandola, M., Rathore, S., Kumar, B., 2011. Indigenous pest management practices prevalent among hill farmers of Uttarakhand. Indian Journal of Traditional Knowledge 10(2), 311-315.

Deka, M.K., Bhuyan, M., Hazarika, L.K., 2006. Traditional pest management practices of Assam. Indian Journal of Traditional Knowledge 5(1), 75-78.

Gorjestani, N., 2000. Indigenous knowledge for development: opportunities and challenges. UNCTAD conference on Traditional Knowledge, Geneva, November 1, 1-8.

Gupta, A.D., 2011. Does Indigenous Knowledge have anything to deal with Sustainable Development?. Antrocom Online Journal of Anthropology 7(1), 57-64.

Kanwar, P., Sharma, N., 2006. Traditional storage structures prevalent in Himachali homes. Indian Journal of Traditional Knowledge 5(1), 98-103.

Mahalik, P.R., Mahapatra, R.K., 2010. Documenting Indigenous Traditional Knowledge in Odisha. Orissa review, MayJune, 99-103.

Sarangi, S.K., Singh, R., Singh, K.A., 2009. Indian Journal of Traditional Knowledge 8(2), 230-233.

Singleton, G.R., Brown, P.R., Jacob, J., 2004. NJAS-Wageningen Journal of Life Sciences 52(2), 163-171.

Sundaramari, M., Ranganathan, T.T., 2005. Indigenous Agricultural Practices - for sustainable farming. Agrobios publishers, India, 73-78.

Steve, R.B., Chakma, N., Sarker, N.J., Sarker, S.U., Sarker, S.K., Kamal, N.Q., 2009. The Chittagong story: studies on the ecology of rat floods and bamboo masting. In: Singleton, G.R., Belmain, S.R., Brown, P.R., Hardy, B. (Eds.), 2010. Rodent outbreaks: ecology and impacts. Los Banos (Philippines): International Rice Research Institute, 49-63. 